\title{
Legal Basis for Transformation of Public Property and Russian Legislation on Privatization in the 1990s
}

\section{凡目 Alexander Kozyrin}

Professor, Department of Financial, Tax and Customs Law, Law Faculty, National Research University Higher School of Economics, Doctor of Juridical Sciences. Address: 20 Myasnitskaya Str., Moscow 101000, Russia. E-mail: ankozyrin@gmail.com

\section{㕵国 Abstract}

The article discusses the history of the legislation on privatization in Russia and features of use of privatization as a regulator of the modern economic policy in the Russian Federation. The author shows the unique experience of privatization in Russia in the 1990s, which allowed rapid creation of private sector in the Russian economy. Privatization as a paradigm of modern economic policies of developed countries has now become truly universal. Having replaced the strategy of state intervention in the economy, the policy of privatization rapidly covered the majority of foreign countries in the early 1970s. In Russia, privatization has become one of the key elements in the system of market reforms and decentralization of the economy. In contrast to countries with developed market economies, where the transfer of the state-owned property into private ownership helped increase the effectiveness of individual enterprises, privatization in Russia was intended to provide a radical shift in property relations. The article analyses different approaches to defining privatization, including the approaches provided for in the legislation in regards to this term, highlights the main stages of the Russian legislation development in the field of privatization. The legislation on the "first wave" of privatization had been launched in 1992, when Russia began the "voucher" privatization (1992-1994) featured by using vouchers as means of payment (hence, this stage was called "voucher" privatization). A privatization voucher did not certify its owner's right to the share in the public property. It was a kind of government security, the yield of which was dependent on the method of its use by the owner. By purchasing shares for privatization vouchers, their owners could earn income through the sale of shares or in the form of dividends to be paid. After the voucher privatization, the government moved towards a new model, known as "monetary privatization". Main reason for transition to monetary privatization was urgent need for federal budget revenues and the need for investment for structural transformation of the Russian economy. The article describes mortgaging auctions, which were among the non-standard forms of privatization used in practice at that period. Individual privatization projects can also be referred to the nonstandard forms. They included measures aimed at privatization of public property particularly important for the state, region or industry, and providing for the pre-sale preparation of the property with assistance of an independent financial consultant.

\section{늘 Keywords}

transformation of public property, privatization, Russian legislation, proceeds from privatization, voucher privatization, mortgaging auctions.

Citation: Kozyrin A.N. (2016) Legal Basis for Transformation of Public Property and Russian Legislation on Privatization in 1990 s. Pravo. Zhurnal Vysshey shkoly ekonomiki, no 4, pp. 140-151 (in English)

DOI: 10.17323/2072-8166.2016.4.140.151 
Privatization as a paradigm of modern economic policies of developed countries has now become truly universal. Having replaced the strategy of state intervention in the economy that had prevailed since the First World War and had even intensified after the global economic crisis of the 1929-1933, the policy of privatization rapidly covered the majority of foreign countries in the early 1970s. It worth noting that until the 1970s there was no concept of privatization in the legal, economic and political lexicon, and there was no mention of it in the dictionaries and reference books of that time. Now, privatization, similar to taxes, is addressed among the most important directions in the election programs of political parties; whole branches of law emerges around it, etc. Privatization has even reached Cuba and other "orthodox" countries with planned economies.

The privatization boom took off in the first half of 1990s. Many countries were actively using the experience of the UK, the "pioneer" of privatization, in their privatization programs. Each country has formed its own set of privatization tools and techniques, taking into account the specifics of the prevailing economic, social and political realities, and coming from the needs of reforming the national structure of ownership ${ }^{1}$.

In the countries of Southern Europe (Italy, Spain, Portugal and Greece) privatization policies were influenced greatly by the urgent need to cover the budget deficit rather than by neoliberalism. There was a different situation was in the north of Europe. In Sweden, Finland, Norway and Denmark, the privatization boom was driven not by fiscal considerations, but primarily by the interests of economic policy: in countries with a traditionally high share of public sector in the economy, privatization was conditioned by the need for structural economic reforms, which were hoped to improve the competitiveness of national industries in global markets and to support rapid transition to high-tech industries.

In countries with developed federalism (for example, in Canada) privatization was carried out mainly at the regional level. Some countries used privatization to fit quickly into the globalization processes of economic relations. Specifically privatization itself was considered in some countries as tool for the formation of a transnational market environment.

Developing countries of the Third World (in Africa, Latin America, Asia-Pacific region), basing their economic policies on the strong public sector, under the influence of the world financial institutions (especially, the World Bank) have adopted the proposed privatization programs and have taken significant cuts in the national public sector.

In Russia, as in most post-Soviet countries, privatization has become one of the key elements in the system of market reforms and decentralization of the economy. "Privatization in Russia was unprecedented not only in scale, but also in content", says the policy brief of the Accounts Chamber of the Russian Federation. "In contrast to countries with developed market economies, where the transfer of the state-owned property into private ownership helped increase the effectiveness of individual enterprises, privatization in Russia was intended to provide a radical shift in property relations, that is, to meet the challenge of changing the economic basis of society"2.

However, implementation of privatization programs in the post-socialist space differed in their effects. While in some countries (China, Baltic countries) privatization caused relatively low socio-economic losses, in Russia, Ukraine and the Central Asian states the privatization campaigns were accompanied by enormous economic and social upheaval.

\footnotetext{
${ }^{1}$ Privatization: Global Trends and National Specifics. V.A. Vinogradov, ed. Moscow, 2006. P. 24.

${ }^{2}$ Analysis of the State-Owned Property Privatization Process in the Russian Federation for the period of 1993-2003 (expert analytical arrangement). S.V. Stepashin, ed. Moscow, 2005. P. 10.
} 


\section{About the Concept of Privatization}

In scholar discourse, the term "privatization" is used in different meanings.

Privatization in the broad sense is defined as "the process occurring in the national economic system for reducing the public sector, as well as structural redistribution of property rights in favor of private capital by reducing the share of the state in the gross national product"3.

The official documents of the US Government contain reference on privatization as a long term strategy to expand the private sector by reducing the public sector.

Privatization, understood in this way, is an element of the state policy of economy deregulation, the implementation of which leads to an increase in the contribution of the private sector to the economic development of society.

Privatization at the macro level involves the transformation of a significant number of economic agents that ultimately leads to considerable changes in the ownership structure of the means of production, reduction in government consumption of goods and services, and strengthening the role of private institutions in socio-economic development.

In the narrow sense of the word, privatization is "the process of limiting the powers of the state as a subject of ownership, management and/or administration, which is initiated by the state and institutionalized by the relevant legislative acts" ${ }^{4}$.

In this meaning, privatization can be understood in different ways. For example, in the UK, privatization means the reduction of state participation in the capital of the company to less than $50 \%$, and in Turkey, privatization is recognized as fulfilled even if the state reserves the greater part of the property in its ownership ${ }^{5}$.

In the model law on privatization offered by the World Bank, privatization refers to transactions resulting in the sale of state-owned enterprises, a substantial part of state property to private entities, or the transfer of control over state enterprises or a substantial part of other state property to individuals (Article 2$)^{6}$.

The legislation of the Russian Federation contains several definitions of privatization. So, according to Article 1 of the Federal Law of December 21, 2001 No. 178-FZ "On Privatization of the State-owned and Municipal Property", privatization is understood as the paid acquisition of property owned by the Russian Federation, subjects of the Russian Federation, municipalities in the property of physical and (or) legal entities for compensation (Article 1).

A similar definition of privatization can be found in the Civil Code of the Russian Federation of November 30, 1994 No. 51-FZ: "Privatization is the process of transfer of the property in the state or in municipal ownership into the ownership of the citizens and of the legal entities in the order, stipulated by the laws on privatization of the state and municipal property» (Article 217).

Doctrinal definitions of privatization in some cases may differ from the legislated ones. Some Russian and foreign scientists, defining privatization, mean not only the process of transferring public property, but also the implementation of measures to reduce the impact of the public sector and, accordingly, to strengthen the position of the private sector in the economy and to promote business activity in the country ${ }^{7}$.

${ }^{3}$ Vinogradov V.A., Veselovskiy S.Ya. Privatization in the Global Context. Moscow, 1998. P. 15.

${ }^{4}$ Ibid. P. 14-15.

${ }^{5}$ The State Property Management / V.V. Koshkin, V.M. Shupyro, eds. Moscow, 1997. P. 249.

${ }^{6}$ Law on Privatization. Prepared by the Legal Reform and Private Sector Development Unit, Legal Department, The World Bank // http://siteresources.worldbank.org/INTLAWJUSTICE/Resources/privatization_civil. pdf (accessed: 12 .12.2012)

${ }^{7}$ See: Paschenko A.V. Purposes of the Legal Regulation of Privatization // Reforms and Law. 2012. No. 2. P. 15,16 . 
This concept of privatization allows, for example, distinguishing between privatization of property (proprietary privatization), the object of which is the ownership right, and privatization of functions (functional privatization), when certain functions of the state and competencies of public authorities are transferred to institutions of private law (various associations, unions, self-regulatory organizations, and so on) within the framework of liberalization of public administration and state regulation ${ }^{8}$.

When defining privatization, the historical features of public property formation and augmentation in some post-socialist states should be also taken into account.

Currently, such concepts as gratuitous transfer of state-owned and municipal property have emerged in their legislation, establishing the legal framework for public property. Obviously, this legal model of public property alienation is not privatization in the above sense, and it resembles the "return" of state-owned property in cases when restitution tools are not used.

Examples of such specific cases of public property transfer in the Russian Federation are presented in the legislation on privatization of the state-owned and municipal housing fund ${ }^{9}$, as well as in the Special Procedure for the transfer of religious buildings and constructions with related land and other state-owned or municipal property of religious purposes into the ownership of religious organizations for use in their respective order ${ }^{10}$.

\section{Development of Legislation on Privatization in Russia: Economic Reforms and Improvement of Public Finances}

The objectives of privatization in the Russian Federation differed significantly from those of privatization campaigns in the West.

Privatization in Russia has become one of the ways of denationalizing economy and transitioning to a market economy. Without solving this initial task, the Russian Government would not be able to move on to the "classic" purposes of privatization (economic reforms, improvement of public finances, and so on).

The origins of the modern legal model of privatization in Russia should be sought in the second half of the 1980s. At this historical stage of privatization, which is called "creeping"11 ("free"12,

${ }^{8}$ Parker D. Privatization Ten Years on: a Critical Analysis of its Rationale and Results". https://dspace.lib. cranfield.ac.uk/bitstream/1826/606/2/SWP4091.pdf (accessed: 12.12. 2012)

${ }^{9}$ The legislative regulation of privatization of the housing fund in the state and the municipal ownership is characterized by, firstly, being carried out in accordance with the "own" law on privatization, Law of the Russian Federation of July 10, 1991 No. 1541-1 “On Privatization of the Housing Fund in the Russian Federation”, and, secondly, being closely connected with the Russian housing legislation.

${ }^{10}$ In accordance with the Federal Law of June 25, 2002 No. 73-FZ "On the Objects of Cultural Heritage (monuments of history and culture) of the Peoples of the Russian Federation", the objects of cultural heritage of religious purpose may be transferred to religious organizations' property only in compliance with the order established by the legislation of the Russian Federation (Para 2, Article 50). The relevant procedure is provided for in the Federal Law of September 26, 1997 No. 125-FZ "On Freedom of Conscience and on Religious Associations", which stipulates the principle of a gratuitous transfer of religious buildings and constructions with related land and other property of religious purpose owned by the state and municipalities into the ownership of religious organizations (Para 3, Article 21). It is also regulated by the Federal Law of November 30, 2010 No. 327-FZ "About Transfer of the State-owned or Municipal Property of Religious Purposes to Religious Organizations", which establishes procedures of a gratuitous transfer of this type of public property into ownership.

${ }^{11}$ Privatization in Russia / A.B. Chubais, ed. Moscow, 1999.

${ }^{12}$ Alekseev S.S. Property Right. Issues in Theory. $3^{\text {rd }}$ ed. Moscow, 2010. 
"bureaucratic"13) privatization, the economic relations on privatization began to develop defacto. However, they were not regulated legislatively.

The legislative framework of privatization began to emerge in the early 1990s. The Law of the RSFSR of July 3, 1991 No. 1531-1 "On Privatization of State-owned and Municipal Enterprises in the RSFSR" provided the first legal definition of privatization: "Privatization of state-owned and municipal enterprises is a purchase by citizens, joint stock companies (partnerships) from the government and local Councils of People's Deputies of enterprises, workshops, factories, departments, other independent divisions of these companies; equipment, buildings, constructions, licenses, patents and other tangible and intangible assets of liquidated companies and their divisions; shares (stocks) of the state and local Councils of People's Deputies in the capital of joint stock companies (partnerships); shares (stocks) of privatized companies in the capital of other joint stock companies (partnerships), associations, concerns, unions and other consolidated companies" (Article 1).

Along with the previously mentioned Law of the RSFSR "On Privatization Of State-owned and Municipal Enterprises in the RSFSR" the legislation on the "first wave" of privatization included two more laws: the Law of the RSFSR of December 24, 1990 No. 443-1 "On Ownership", and the Law of the RSFSR of December 25, 1990 No. 445-1 “On Enterprises and Entrepreneurial Activity".

In pursuance of the legislation on privatization and aiming to accelerate privatization processes the Supreme Council of the Russian Federation adopted the Resolution "On differentiation of the state-owned property in the Russian Federation between federal property, public property of the republics in the structure of the Russian Federation, territories, regions, autonomous regions, autonomous districts, Moscow City and Saint-Petersburg City, and municipal property" (December 27, 1991 No. 3020-1).

The legislation on the "first wave" of privatization had actually been launched in 1992, when Russia began the "voucher" privatization (1992-1994).

Mass privatization started in Russia in accordance with the Decree of the President of the Russian Federation of July 1, 1992 No. 721 "On organizational measures for transformation of the stateowned enterprises, voluntary associations of state-owned enterprises into joint stock companies".

The first stage of privatization was featured by using vouchers as means of payment (hence, this stage was called "voucher" privatization). In compliance with Para 1 of the Presidential Decree of August 14, 1992 No. 914 "About Enacting the System of Privatization Vouchers in the Russian Federation" (hereinafter Decree No. 914), the system of privatization vouchers was introduced in the country starting from October 1, 1992 "in order to accelerate the transfer of public property to citizens of Russia and to involve public at large into privatization processes".

According to Decree No. 914 every citizen of the Russia was granted the right to receive one privatization voucher of equal nominal value per issue. Voucher issues were released on the basis of decrees of the President of the Russian Federation. Para 3 of the Decree contained a rule prohibiting "the issuance of securities or the creation of other systems for unpaid transfer of the state-owned and municipal property into the ownership of citizens of the Russian Federation and their associations in republics, territories, regions, autonomous region, cities of Moscow and St.-Petersburg, districts and cities".

Decree No. 914 approved the Regulations on Privatization Check, according to which, privatization checks become the tools of "the mechanism of unpaid transfer to citizens of the Russian Federation of enterprises, their divisions, stocks and shares in joint stock companies and partnerships", being in federal ownership and in the ownership of subjects of the Russian Federation in the course of privatization.

${ }^{13}$ Economic History of the USSR and Russia in the late 20th century (1985-1999). A.A. Klishas., ed. Moscow, 2011. P. 117. 
A privatization check was recognized as a special-purpose non-reusable government security: once used to purchase privatized property it was then cancelled and redeemed from circulation.

Each privatization voucher had a validity determined at its release by the Government of the Russian Federation and indicated on the voucher. The validity could not be less than one year and could not exceed two years. Upon expiration of validity, the privatization checks were considered cancelled and were redeemed from circulation.

According to the Regulations on the Sale of Shares in the Course of Privatization and the Regulations on Private Subscription, approved by the State Property Committee of the Russian Federation, the value of privatization objects could be paid in full or in part by privatization checks ${ }^{14}$.

When buying a whole enterprise, as well as assets of liquidated enterprises at auction, competitive or investment tender, a buyer was obliged to make part of the payment in privatization checks within the limits of proceeds from privatization to be directed to the federal budget according to the rates established by the state privatization program.

The Russian Federal Property Fund or other institution, acting as a representative of the seller of the privatization object, was obliged to accept privatization checks at their face value as legal means of payment.

We should also note that, when issuing vouchers, there was no calculation stipulated to determine the share value of privatized enterprises relevant to the value of a privatization check $^{15}$.

A privatization voucher did not certify its owner's right to the share in the public property. It was a kind of government security, the yield of which was dependent on the method of its use by the owner. By purchasing shares for privatization vouchers, their owners could earn income through the sale of shares or in the form of dividends to be paid.

A privatization check gave the holder the right to buy shares of privatized enterprises in the whole territory of the Russian Federation, as well as shares of the check investment funds.

In order to create necessary conditions for vouchers' circulation, the Decree of the President of the Russian Federation of October 7, 1992 No. 1186 "On Measures for organization of securities market during the process of privatization of the state-owned and municipal enterprises" provided for the establishment of check investment funds - CIFs, which were to accumulate privatization checks for subsequent investments in shares of privatized enterprises. The CIFs accepted privatization checks (vouchers) from the population in exchange for shares of the funds. For vouchers they purchased shares of various privatized companies, and paid dividends to their stockholders from the sum of dividends received on the shares of the invested enterprises.

Presidential Decree of February 12, 1993 No. 216 "On Measures to Regulate the Circulation and Redemption of Privatization Checks" established that privatization checks could be bought and sold without restriction as to number. The prices of privatization checks were determined by consensus between parties.

According to the State Program of privatization of state-owned and municipal enterprises in the Russian Federation, approved by Presidential Decree of December 24, 1993 No. 2284, small enterprises were to be sold at auctions and tenders. Privatization of large enterprises was carried out after reorganizing them into joint stock companies. In this case, the workers were entitled to preferential buyout of certain percentage of shares of privatized companies by private subscription.

${ }^{14}$ Directive of the State Property Committee of Russia of July 27, 1992 No. 308-r "On Adoption of Regulations on Private Placement of Shares in the Privatization Process of the State-Owned and Municipal Enterprises"; Directive of the State Property Committee of Russia of November 4, 1992 No. 701-r "On Adoption and Introduction of Regulations on Sale of Shares in Process of Privatization and Regulations on the Special Check Auctions".

${ }^{15}$ Ministry of Economic Development of the Russian Federation. Letter, April 16, 2009 No. D06-1043. 
Citizens of the Russian Federation, who were not the employees of enterprises to be privatized, had the opportunity to participate in privatization of enterprises through specialized voucher auctions and CIFs. The number of shares to be sold for one privatization voucher was determined by specialized voucher auctions.

It should be mentioned that sale and purchase operations with privatization vouchers and acquiring securities in exchange for vouchers, including shares of the check investment funds and shares of privatized enterprises, were not subject to taxation. In addition, the cost of privatization vouchers issued to the persons entitled to receive them in accordance with the Russian legislation was not included in the taxable gross income of citizens and was not subject to income tax on individuals. Personal income obtained in the form of the difference between the share value of the check investment funds at its initial placement and its value at subsequent sale at a higher price was also not subject to tax.

As already noted, the funds raised from privatization were distributed according to the standards set in the State Privatization Program.

The proceeds from privatization of federal property or the property of subjects of the Russian Federation, after payments made to members of labor collectives, were to be distributed as follows: $45 \%$ of the funds were directed to the budget of the constituent entity of the Russian Federation, $30 \%$ - to the federal budget, and $10 \%$ - to the local budget. The remaining $15 \%$ of proceeds were allocated among the Federal Entrepreneurship Development Fund (5\%), the State Property Committee $(1.7 \%)^{16}$, the Russian Federal Property Fund (0.3\%), the regional agency of the State Property Committee (4.5\%) and the Regional Property Fund ${ }^{17}$ (3.5\%).

In the case of privatization of municipal property, the norms of distribution were changed in favor of local budgets: $45 \%$ of the funds were directed to the local budget, $25 \%$ - to the budget of the subject of the Russian Federation, and $20 \%$ - to the federal budget. The remaining 10\% was distributed among the State Property Committee (1.7\%), the Russian Federal Property Fund $(0.3 \%)$, the regional agency of the State Property Committee $(4.5 \%)$ and the Regional Property Fund (3.5\%).

Proceeds from the sale of property in the operative management of the Armed Forces, the Federal Counterintelligence Service, and the Ministry of Internal Affairs were transferred in full $(100 \%)$ to the federal budget. One per cent of the funds were used to stimulate activity of the organizers of the privatization process.

"Voucher" privatization is probably one of the most controversially and ambivalently assessed pages of the modern economic history of Russia. On the one hand, vouchers contributed to the denationalization of the economy, the creation of the institution of private property, and the formation of the corporate sector and the corporate securities market. As of July 1, 1994, the share of the private sector in the consumer goods industry accounted for $48 \%, 47 \%$ in the food industry, $35 \%$ in construction, $42 \%$ in mechanical transport and vehicle repair, $55 \%$ in retail trade, $47 \%$ in public catering, and $55 \%$ in domestic services ${ }^{18}$.

On the other hand, vouchers were not able to ensure equitable and fair privatization of state-owned property. Methods of voucher privatization were inherently non-economic, and fierce debates on its "predatory essence" still continue to this day.

${ }^{16}$ At least $50 \%$ of funds from privatization received by the State Property Committee were directed to conducting the voucher auctions. If as a result of the check auctions and check investment tenders, the lack of monetary component for the transfer to the privatization bodies according to the established standards was detected, the missing funds were financed by the local budget. These funds were managed by a team, consisting of representatives of the State Property Committee of Russia and the Russian Federal Property Fund.

${ }^{17}$ The Fund of the state national, territorial national and administrative territorial formations.

${ }^{18}$ Radygin A.D. Reform of Property in Russia: On the Way from the Past to the Future. Moscow, 1994. P. 155. 
The initial mechanism of privatization had a combined nature. Privatization for all, being assumed to distribute privatization coupons (vouchers) among the entire population, was combined with the distribution of property among a company's employees. The elements of nonpaid privatization were closely interwoven with the basics of paid privatization. This mixed model of privatization has provoked the emergence of a number of serious economic problems (lack of required investments, valuation of property by the residual method, and so on) ${ }^{19}$ and has eventually led to the fact that a significant number of shares have never been sold.

After the failure of voucher privatization, the government moved towards a new model, known as "monetary privatization". The main reason for the transition to monetary privatization was the urgent need for budget revenues at the federal level and the need for investment for structural transformation of the Russian economy.

Presidential Decree of July 22, 1994 No. 1535 "On the Main Provisions of the State Privatization Program of State-owned and Municipal Enterprises in the Russian Federation after July 1, 1994" has became the starting point in the formation of new regulators of privatization. It established the following main goals of privatization after the expiration of privatization vouchers:

- Efficiency improvement of the Russian economy in general and the activity of individual companies;

- Formation of a broad stratum of private owners and support to the emergence of strategic private owners;

- Promotion of industrial investments, including foreign ones;

- Support to implementation of social protection and the protection of private property owners' (shareholders') rights.

Three years after the beginning of monetary privatization, Federal Law of July 21, 1997 No. 123-FZ "On Privatization of the state-owned property and the Principles of municipal property privatization in the Russian Federation" was adopted. As conceived by the legislator, the emphasis in the new law is shifted towards privatization of the public property shares in joint stock companies.

Article 4 of the Federal Law No. 123-FZ provided for the adoption of the federal law on the state privatization program of state-owned property, which should establish priorities for stateowned property privatization in the Russian Federation, privatization restrictions, the order of transfer of state-owned property into the ownership of physical and legal persons, and the principles of municipal property privatization.

The State Privatization Program was designed to respond quickly to changes in economic policy. For these purposes, it was provided that the Government of the Russian Federation, when submitting the annual draft law on the federal budget to the State Duma, should also submit a draft federal law on introducing amendments to the privatization program.

In practice, however, this federal law was not adopted, and privatization continued to be based on revisions to the previously accepted programs - the State Privatization Program of state-owned and municipal enterprises in the Russian Federation, approved by Presidential Decree of December 24, 1993 No. 2284, and the Main Provisions of the State Privatization Program of state-owned and municipal enterprises in the Russian Federation after July 1, $1994^{20}$, approved by Decree of July 22, 1994 No. 1535.

Federal Law No. 123-FZ provided that the funds gained from privatization should be distributed in accordance with the standards established by the privatization program, and respectively be transferred to the federal budget, the budgets of subjects of the Russian Federation and

\footnotetext{
${ }^{19}$ Economic History of the USSR and Russia in the late XX century... P. 122-123.

${ }^{20}$ The official date of completion of voucher privatization.
} 
local budgets (Article 13 of the Federal Law No. 123-FZ). The legislator has fixed the binding nature of the payments and granted exemption from taxation.

In case of delay in transfer of funds from privatization, the tax authorities had the right to withdraw such funds from the accounts of the state property sellers on an uncontested basis. In this situation, the sellers of the public property had to also pay a fine for each day of delay at the rate of $1 / 300$ of the refinancing rate of the Bank of Russia on the date of the seller's monetary liabilities to the budget.

As in the case of voucher privatization, monetary privatization faced the need for regulatory adjustments due to economic factors, the extent of which has not been addressed by lawmakers: enterprises, going through default of payments and enormous debt, including non-payments to the federal budget; the lack of demand for shares in most privatized enterprises, and so on. It should be also taken into consideration that the course of privatization in that period was significantly influenced by political factors associated with the presidential elections of 1996.

And against such a challenging socio-economic and political background, the state demonstrated its intention to increase budget revenues at any cost, selling out public assets.

It is obvious that the practice of privatization was influenced by the aforementioned circumstances. As a result, the so-called non-standard forms of privatization emerged: mortgaging auctions, individual privatization projects, socially oriented commercial tenders ${ }^{21}$ and others.

Mortgaging auctions were among these non-standard forms of privatization used in practice at the end of 1995. The public shareholding of such major companies as "YUKOS", "Norilskiy Nikel", "Sibneft", "Sidanko", "Surgutneftegaz", Novolipetsk Metallurgical Works, Novorossiysk Steamship Company and others passed into the ownership of a number of commercial banks through mortgaging auctions.

Regulation of mortgaging auctions was based on the Presidential Decrees of August 31, 1995 No. 889 "On the Procedure of pledging federal property shares in 1995", of September 30, 1995 No. 986 "On the Procedure of decision-making on the management and disposal of federal property shares", of November 2, 1995 No. 1067 "About the Time-frame of the sale of federal property shares, passed to pledge in 1995", and of December 7, 1995 No. 1230 "Issues of passing federal property shares to pledge in 1995".

In accordance with the scheme of holding mortgaging auctions, the Government of the Russian Federation obtains loans from commercial banks against pledges of shareholdings. It was planned to hold auctions ${ }^{22}$ for the right to conclude loan agreements with the Russian Federation against pledges of federal property shares. The Ministry of Finance of Russia has entered into loan agreements with the winners of such auctions. Upon the expiry of the set time, the Government had to repay the loans, and in the case of credit default the state-owned shareholdings passed into the ownership of the creditors. The Government of the Russian Federation has not repaid the loans, and the public shareholdings have been transferred to the ownership of the banks, the winners of the mortgaging auctions.

The income gained from pledging the federal property shares was distributed according to the standards approved by the Decree of the President of the Russian Federation of August 31, 1995 No. $889: 80 \%$ of total revenues were transferred to the federal budget, $15 \%$ - to the budgets of subjects of the Russian Federation, and 5\% - to local budgets.

Individual privatization projects can be also referred to the nonstandard forms. They included "measures aimed at privatization of federal property particularly important for the state, region or industry, and providing for the pre-sale preparation of the property with assistance of

\footnotetext{
${ }^{21}$ Economic History of the USSR and Russia in the late 20th century... P. 124.

${ }^{22}$ Regulations for auctions were approved by the Presidential Decree of August 31, 1995 No. 889 "On the Procedure of Passing Federal Property Shares to Pledge in 1995”.
} 
an independent financial consultant". The implementation procedure of such individual privatization projects was approved by the Resolution of the Government of the Russian Federation of April 1, 1997 No. 363.

Along with investment promotion, necessary for the production, technological and social development of privatized enterprises, and the improvement of privatized property use, the fiscal task was one of the main objectives of implementing the individual privatization projects. They were to "maximize the federal budget income gained from privatization of property through increasing the value of this property as a result of the financial consultant's activity" (Section 1 of the Procedure approved by the Resolution of the Government the Russian Federation No. 363).

Financial consultants were engaged to assess the market value of the property to be privatized and to develop recommendations regarding restructuring of the property, as well as the time and method of its sale. The selection of financial consultants was carried out by tender considering the characteristics of the proposal, the cost of the consultant's services and professional capabilities (the financial consultant should have an experience in public offering of securities, including in the international market, and have a staff involved previously in the organization of the privatization process). The list of the federal property to be privatized through individual projects was approved by the Government of the Russian Federation upon proposal of the State Property Committee ("Karelsluda" Mining and Processing Plant, Taganrog Commercial Seaport, "Mosfilm", JSC "Rosgosstrakh" and others).

Monetary privatization of the second half of the 1990s became one of the budgetary sources assumed to support the Government to compensate for the tax shortfall to the federal budget.

Financial effect of privatization in the second half of the 1990s can be evaluated by the following aggregated indicators.

6,000 enterprises were privatized in 1995. Income gained from privatization, according to the federal budget, amounted to 4.991 trillion rubles (in current prices), in fact it amounted to 7.319 trillion rubles. Over $70 \%$ of the actual income from privatization in 1995 was provided by mortgaging auctions.

5,000 enterprises were privatized in 1996; the budget indicators constituted 12.3 trillion rubles, but, in fact, the budget received only 1.32 trillion.

In 1997, the budget law established 6.525 trillion in revenue from the privatization of 3,000 enterprises, and, actually, the revenues amounted to 18.1 trillion (significant financial results were obtained due to the sale of shares of the "Svyazinvest" holding company).

In 1998, the budget provided for gaining 8.125 billion from privatization transactions. In fact, privatization of 2,583 enterprises brought in 15.442 billion to the budget, of which 12.5 billion Rubles were received from the sale of $2.5 \%$ of RAO "Gazprom" shares ${ }^{23}$.

It seems that the time has not come yet for final evaluation of the efficiency of privatization proceeds from holding mortgaging auctions. We will confine ourselves to a few evaluative statements on this issue.

Thus, the report of the Accounts Chamber published in 2004, notes that "as a result of mortgaging auctions the alienation of federal property has been carried out at significantly underestimated prices, and the competition actually had an artificial character" ${ }^{24}$. The report contains facts giving rise to a critical assessment of the results of practicing this nonstandard form of privatization. At only four of twelve auctions held at the end of 1995, the loan amount signifi-

${ }^{23}$ Economics of Transition: Essays of Economic Policy of Post-Communist Russia (1998-2002). Moscow, 2003. P.342-343; Economic History of the USSR and Russia in the late XX century... P. 128.

${ }^{24}$ Analysis of the State-Owned Property Privatization Processes in the Russian Federation for 1993-2003 // http://www.r-reforms.ru/priv22.htm\#3 ( accessed: 12 November 2012). 
cantly exceeded the initial price. Actually, the banks "lent" the state its own money: Ministry of Finance had to transfer funds to the accounts of the consortium member-banks in an amount equal to the loan value, and then the money was to be transferred to the Government as a loan secured by the shares of the most attractive enterprises. Contrary to the rules of auctions, the banks did not transfer the loan funds to the account of the Bank of Russia; the funds were kept in the same commercial banks on special accounts, and so on.

In late 1995, based on the results of an audit, the Accounts Chamber submitted information letters to the Chairman of the Government, heads of the Federation Council and the State Duma, Prosecutor General and the Minister of Justice. The letters justified the conclusion about the ineffectiveness of mortgaging auctions and the requirement to abandon them.

Paul Khlebnikov, commenting on the results of the mortgaging auction for YUKOS, wrote, referring to one of the "oligarchs", "Buying the state-owned assets through a backroom deal and at such a low price, you run the risk that your rights for the new property will never be reliably protected. Citizens will consider you a fraud, and the state will see you rather custodian than the beneficial owner of assets"25.

There were several attempts to estimate the results of privatization in the 1990s undertaken by different government and political institutions and researchers, economists and lawyers. Almost all of them agreed that the mass privatization in Russia was launched before the necessary organizational and legal basis had been formed. The underdevelopment of legal, regulatory, and institutional prerequisites for carrying out such large-scale reforms of state-owned property [together with?] the lack of effective external control, led to significant abuse, owing to which privatization in the public mind was associated with shady financial transactions.

When trying to give an objective assessment of the privatization campaigns of the 1990s, divergent opinions clash and ultimately lead to ambiguous and contradictory results.

On the one hand, privatization helped radically change the structure of ownership in the Russian Federation. According to the estimates in the abovementioned report of the Accounts Chamber, as of 2003, the share of private property in Russia amounted to $77 \%$. The share of state-owned property comprised $4 \%$, of municipal property, $6 \%$, the rest $13 \%$ of property was in combined ownership (state and private) ${ }^{26}$. The emergence of the institution of private property in Russia led to the development of market economic relations and modern market infrastructure.

On the other hand, the realities of privatization of the 1990s included privatization projects of an "insider" nature, when the state-owned property was transferred to the management (industrial managers) of privatized enterprises on "special terms". One of the outcomes of privatization of the 1990s in Russia, according to the World Bank, was the world's highest concentration $^{27}$ of private property among a small group of individuals, objectively hampering the competitiveness of the Russian economy. It should be also noted that privatization became the second heavy attack on industrial relations after the collapse of the USSR: the conversion of privatized enterprises in some cases led to considerable negative consequences for the economy.

An attempt to summarize the results of privatization of the 1990s was undertaken in the Concept of State Property Management and Privatization in the Russian Federation, approved by the Resolution of the Government of the Russian Federation of September 9, 1999 No 1024. It was stated in the Concept that "despite the fact that $58.9 \%$ of enterprises became private due to the mass privatization, some goals were not achieved:

${ }^{25}$ Khlebnikov P. Case of YUKOS: the Milestone on the Path to Legality. Vedomosti. No. 45 (234). 18 November 2003.

${ }^{26}$ Analysis of the State-Owned Property Privatization Processes in the Russian Federation for the Period of 1993-2003 ... http://www.r-reforms.ru/priv22.htm\#3 (Date of access: 12 November 2012).

${ }^{27}$ Economic History of the USSR and Russia in the late XX century... P. 133. 
- the stratum of effective private owners has not been formed;

- the economic restructuring did not lead to the desired improvement of the enterprises' efficiency;

- the volume of investment promoted through privatization is clearly insufficient for industrial, technological and social development of enterprises;

- in some industries, the competitive position of enterprises on domestic and global markets has failed to be maintained".

To eliminate the negative tendencies of privatization campaigns, it is necessary to develop new approaches addressing the issues related to state property management, and to update the legislation on privatization.

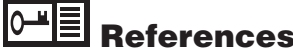

Alekseev S.S. (2010) Pravo sobstvennosti. Problemy teorii. [Property Right. Issues of Theory]. 3rd ed. Moscow: Norma, 239 pp. (in Russian)

Chubays A.B. (ed.) (1999) Privatizatsiya po-rossiyski [Privatization in Russian Way). Moscow: Vagrius, 367 pp. (in Russian)

Gaidar E. (ed.) (2003) Ekonomika perekhodnogo perioda. Ocherki ekonomicheskoy politiki postkommunisticheskoy Rossii (1998-2002) [Economics of Transition: Essays of Economic Policy of Post-communist Russia (1998-2002). Moscow: Delo, 832 p. (in Russian)

Khlebnikov P. (2003) Delo «YuKOSA»: vekha na puti k zakonnosti [The YUKOS Case: the Milestone on the Path to Legality]. Vedomosti, no. 45 (234).

Klishas A.A. (ed.) (2011) Istoriya ekonomiki SSSR i Rossii v kontse XX veka (1985-1999) [Economic History of the USSR and Russia in the late20th century (1985-1999)]. Moscow: Moscow State University Publishing, 272 p. (in Russian)

Koshkin V.V. (ed.) (2002) Upravlenie gosudarstvennoy sobstvennost'yu [The State Property Management]. Moscow: Eksmo Publishing, 662 pp. (in Russian)

Kozyrin A.N. (2012) Privatizatsiya v Rossii: pravovoe izmerenie [Privatization in Russia: Legal Dimension] Reformy i pravo, no 2, pp. 3-14 (in Russian)

Kozyrin A.N. (ed) (2012) Privatizatsiya i pravo [Privatization and Law] Moscow: HSE Publishers, 231 p. (in Russian)

Parker D. Privatization Ten Years on: a Critical Analysis of its Rationale and Results. Available at: https://dspace.lib.cranfield.ac.uk/bitstream/1826/606/2/SWP4091.pdf

Radygin A.D. (1994) Reforma sobstvennosti v Rossii: na puti iz proshlogo v budushchee [Reform of Property in Russia: On the Way from the Past to the Future]. Moscow: Respublika, 159 pp. (in Russian)

Stepashin S.V. (ed.) (2005) Analiz protsessov privatizatsii gosudarstvennoy sobstvennosti v Rossiyskoy Federatsii za period 1993-2003 (ekspertno-analiticheskoe meropriyatie) [Analysis of the State-Owned Property Privatization Process in the Russian Federation for the period 1993-2003 (expert analytical arrangement ]. 2nd ed. Moscow: Olita, 186 pp. (in Russian)

Vinogradov V.A., Veselovskiy S.Ya. (1998) Privatizatsiya $v$ global'nom kontekste. [Privatization in the Global Context]. Moscow: INION Publishing, 120 pp. (in Russian)

Vinogradov V.A. (ed.) (2006) Privatizatsiya: global'nye tendentsii i natsional'nye osobennosti [Privatization: Global Trends and National Specifics]. Moscow: Nauka, 366 p. (in Russian)

Yalbulganov A. (2012) Pravovoe regulirovanie privatizatsii zemel'nykh uchastkov [Institutional and Legal Framework of Land Privatization in the Russian Federation]. Reformy i pravo, no 4, pp. 40-47 (in Russian) 